\title{
Temperature dependence of secondary organic aerosol yield from the ozonolysis of $\beta$-pinene*
}

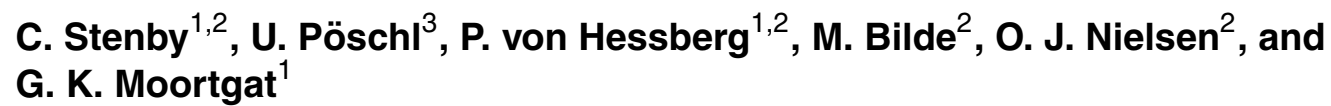

${ }^{1}$ Atmospheric Chemistry Department, Max Planck Institute for Chemistry, J.J. Becherweg 29, 55128 Mainz, Germany

${ }^{2}$ Copenhagen Center for Atmospheric Research, Department of Chemistry, University of Copenhagen, Universitetsparken 5, 2100 Copenhagen $\varnothing$, Denmark

${ }^{3}$ Biogeochemistry Department, Max Planck Institute for Chemistry, J.J. Becherweg 29, 55128 Mainz, Germany

Received: 4 September 2006 - Accepted: 4 October 2006 - Published: 16 October 2006

Correspondence to: C. Stenby (stenby@mpch-mainz.mpg.de)

${ }^{*}$ Invited contribution by C. Stenby, one of the EGU Outstanding Young Scientist Award winners 2005
Temperature dependence of SOA yield

C. Stenby et al.

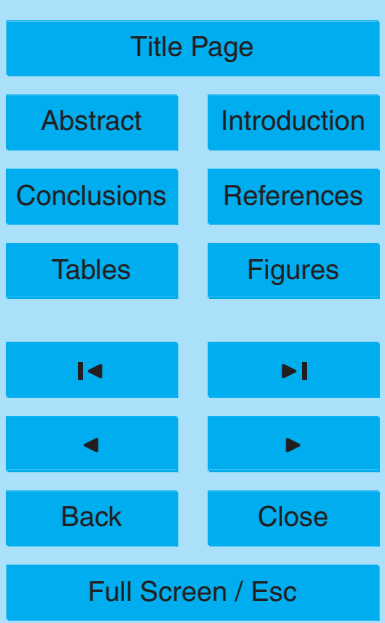

Printer-friendly Version

Interactive Discussion 


\section{Abstract}

The temperature dependence of secondary organic aerosol (SOA) formation from ozonolysis of $\beta$-pinene was studied in a flow reactor at $263-303 \mathrm{~K}$ and $1007 \mathrm{hPa}$. The observed SOA yields were of similar magnitude as predicted by a two-product model

5 based on detailed gas phase chemistry (Jenkin, 2004), reaching maximum values of 0.22-0.39 at high particle mass concentrations. However, the measurement data exhibited significant deviations (up to $50 \%$ ) from the predicted linear dependence on inverse temperature. When fitting the measurement data with a two-product model, we found that both the partitioning coefficients $\left(K_{o m, i}\right)$ and the stoichiometric yields $\left(\alpha_{i}\right)$ of the low-volatile and semi-volatile species vary with temperature. The results indicate that not only the reaction product vapour pressures but also the relative contributions of different gas-phase or multiphase reaction channels are dependent on temperature. We suggest that the modelling of secondary organic aerosol formation in the atmosphere needs to take into account the effects of temperature on the pathways and 15 kinetics of the involved chemical reactions as well as on the gas-particle partitioning of the reaction products.

\section{Introduction}

Atmospheric aerosol particles affect the atmosphere and climate by absorption and scattering of radiation, by influencing the formation and properties of clouds and precipitation, and by heterogeneous and multiphase chemical reactions. Forests and other vegetation emit large amounts of biogenic volatile organic compounds (BVOCs) (500$1800 \mathrm{Tg} \mathrm{C} \mathrm{yr}^{-1}$ ). Besides isoprene monoterpenes are the most abundant BVOCs, and with an emission rate of $10-50 \mathrm{Tg} \mathrm{C} \mathrm{yr}^{-1} \beta$-pinene is the second most important monoterpene (Wiedinmyer et al., 2004). Biogenic secondary organic aerosol (SOA)

25 are formed from oxidation of BVOCs in the atmosphere by $\mathrm{O}_{3}, \mathrm{OH}$ and $\mathrm{NO}_{3}$ radicals, producing low volatility compounds which condense on newly formed or pre-existing

\section{Temperature dependence of SOA yield \\ C. Stenby et al.}

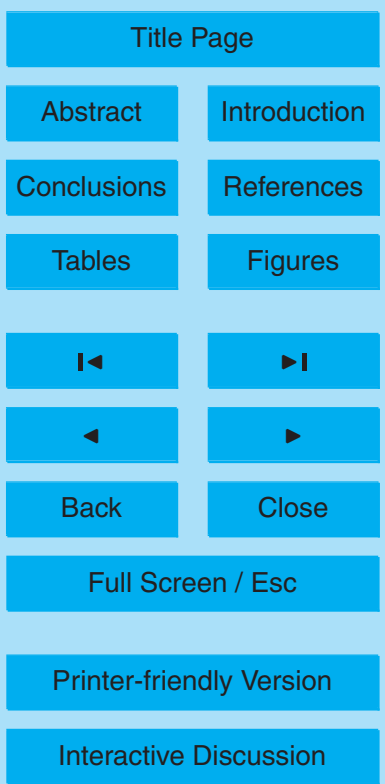


particles. In current global atmospheric models the monoterpenes are usually assumed to account for most if not all SOA formation (Kanakidou et al., 2005), and recent laboratory studies demonstrated the ability of SOA from monoterpenes to affect cloud properties and lifetime by acting as cloud condensation nuclei (Hartz et al., 2005; Van-

5 Reken et al., 2005). Recently the temperature dependence of SOA formation from ozonolysis has been modeled by Sheehan and Bowman (2001), and their parameterization has been incorporated into some advanced Global Atmospheric Models (Chung and Seinfeld, 2002; Tsigaridis and Kanakidou, 2003). Still these models appear to underestimate the organic aerosol particle mass in the free troposphere, which may be 10 due to shortcomings in the characterization and representation of temperature dependencies of SOA formation (Heald et al., 2005). To our knowledge only one experimental study has investigated the temperature dependence of SOA yield (Takekawa et al., 2003). For $\alpha$-pinene this study has reported 2.13 times higher yield at $283 \mathrm{~K}$ compared to $303 \mathrm{~K}$, but no other temperature levels or monoterpenes have been investigated.

15 To support the development of more reliable parameterizations of SOA formation in atmospheric models we have investigated the temperature dependence of secondary organic aerosol yield from the ozonolysis of $\beta$-pinene.

\section{Experimental section}

\subsection{Preparation of the reactants}

20 Ozone was generated by UV irradiation with a mercury pen-ray lamp of a flow of synthetic air $\left(79.5 \% \mathrm{~N}_{2}\right.$ and $20.5 \% \mathrm{O}_{2}$, Air Liquide or Westfalen) mixed with nitrogen (99.999\% $\mathrm{N}_{2}$, Air Liquide or Westfalen). The volume mixing ratio of ozone was controlled by varying the ratio of synthetic air to nitrogen. The concentration of ozone was monitored by UV absorption at $254 \mathrm{~nm}$ and calibrated with a commercial ozone monitor

25 (Model 202, 2B Technologies, Inc.) mounted at the outlet of the flow reactor to account for wall loss of ozone.

\section{Temperature dependence of SOA yield \\ C. Stenby et al.}

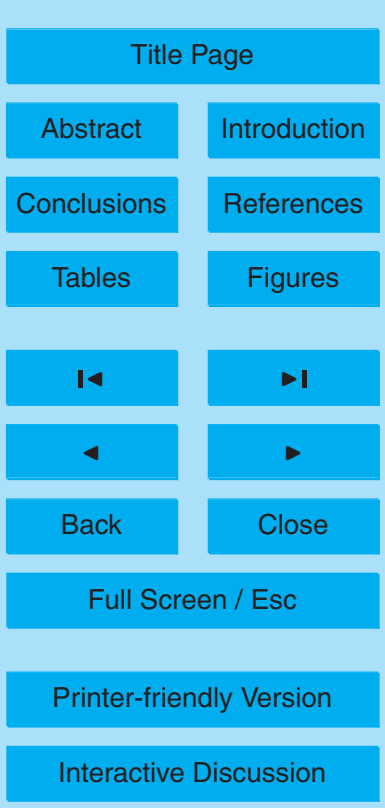

EGU 
$\beta$-pinene (99.5\%) was obtained from Sigma-Aldrich Chemical Co and used as received. It is a liquid with a vapour pressure of $313 \mathrm{~Pa}$ at $293 \mathrm{~K}$. The gas mix of $\beta$ pinene in nitrogen was prepared by evaporating pure $\beta$-pinene into an evacuated steel vessel $(\mathrm{V}=14.67 \mathrm{I})$ and adding nitrogen to a pressure of about $6000 \mathrm{hPa}$; the $\beta$-pinene 5

\subsection{Aerosol formation}

Figure 1 displays a schematic drawing of the experimental set-up applied in this study (described in detail by Bonn et al., 2002). The SOA formation experiments were performed in a vertical flow tube reactor $(120 \mathrm{~cm}$ length, $10 \mathrm{~cm}$ inner diameter, Pyrex glass 10 walls), operated with a laminar gas flow of $5 \mathrm{Imin}^{-1}$ and a center velocity of $2 \mathrm{~cm} \mathrm{~s}^{-1}$ (Bonn et al., 2002). All flows were controlled by MKS mass flow controllers. The temperature was taken into account when converting the volume flow to the mass flow of the flow controllers. The flow of synthetic air and ozone from the pen-ray lamp $\left(0.21 \mathrm{~min}^{-1}\right)$ was mixed with nitrogen to $2.01 \mathrm{~min}^{-1}$ and introduced through the center 15 of the inlet mixing plunger. $\beta$-pinene from the pressurized steel vessel was mixed with synthetic air to a flow of $3 / \mathrm{min}^{-1}$ and introduced at the top of the flow reactor. The two flows were mixed under turbulent conditions in the movable inlet mixing plunger. The reaction time $(\Delta t)$ was controlled by adjusting the distance between plunger and outlet. In the experiments reported here, the distance was kept at $80 \mathrm{~cm}$, to assure that the reactants reach the temperature of the flow reactor before being mixed and to have as long a reaction time as possible and avoid unnecessary high reactant concentrations for achieving well-measurable yields. To vary the amount of reacted $\beta$-pinene, the initial volume mixing ratios of $\beta$-pinene and ozone were varied in over the range of $0.6-10.9 \mathrm{ppmv}$ and $0.2-2.4 \mathrm{ppmv}$, respectively. The decrease of reactant concentration 25 was $0.4-3.9 \%\left(31-1273 \mu \mathrm{g} \mathrm{m}^{-3}\right)$ for $\beta$-pinene and $0.5-14.6 \%$ for ozone.
ACPD

6, 10275-10297, 2006

\section{Temperature dependence of SOA yield \\ C. Stenby et al.}

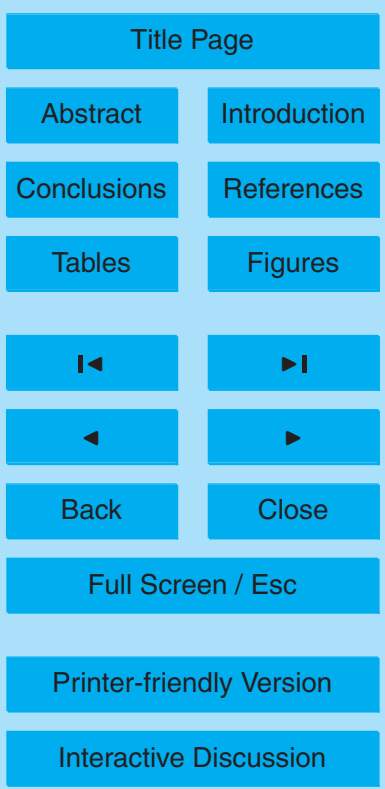




\subsection{Aerosol analysis}

Particle size distributions of the particles formed in the flow reactor were measured with a scanning mobility particle sizer (SMPS) system (Model 3936, TSI Inc.) with a long differential mobility analyzer (LDMA, Model 3081, TSI Inc.) and an ultrafine 5 condensation particle counter (UCPC, Model 3025A, TSI Inc.). The sampling flow rate was $0.31 \mathrm{~min}^{-1}$, and the position of the sampling orifice with a radius of $1.1 \mathrm{~cm}$ was radially centered about $3 \mathrm{~cm}$ above the bottom of the flow reactor. Compared to the reaction time in the flow tube (40 s), the additional time in the neutralizer was negligible $(<1 \mathrm{~s})$. The DMA sheath air flow rate (3 to $9.7 / \mathrm{min}^{-1}$, see Table 1 ) was regulated with

10 a mass flow controller, and the temperature used for conversion of mass to volume flow rate was measured where the sheath air enters the DMA. To minimize ozonolysis inside the DMA, an ozone scrubber consisting of a glass tube filled with silver wool was installed in the sheath air loop, reducing the ozone concentration to the limit of detection (2 ppbv). Due to the ten-fold or higher dilution of the sample flow with ozone15 free sheath air and short residence time (1.5 s), ozonolysis reactions in the DMA were negligible. The silver wool may also have scrubbed reaction products from the gas phase, but we assume that equilibrium was re-established when the sheath air was flowing through the filter collecting the SOA particles.

In each experiment the flow reactor and the SMPS system were kept at a common temperature $( \pm 2 \mathrm{~K})$, using a Julabo F20 cryostat combined with a Julabo FT 401 cooler for the flow reactor and the neutraliser and a MGW Lauda RM6 cryostat for the DMA and the sheath air of the DMA, both of them circulating ethanol/water through glass/steel jackets and a hose wrapped around the DMA as illustrated in Fig. 1. Note that warm and humid conditions in the laboratory can lead to water condensation and short circuiting of the cooled DMA, which can be avoided by using only low voltages.

In every SOA formation experiment, the particle size distribution measurements were repeated 4-24 times. Conditions and results of the individual experiments are summarized in Table 1.

\section{Temperature dependence of SOA yield \\ C. Stenby et al.}

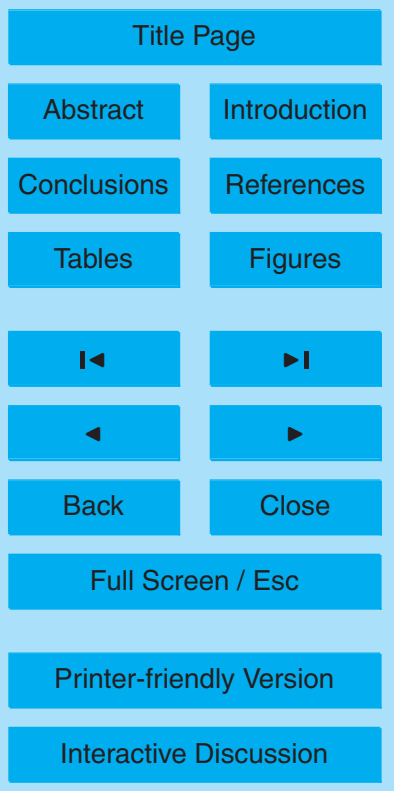




\section{Data analysis and modelling}

\subsection{Data analysis}

SOA formation yields $(Y)$ were calculated by dividing the mass concentration of SOA particles $\left(M_{o}\right)$ by the decrease of $\beta$-pinene mass concentration $(-\Delta[\beta$-pinene $])$ :

${ }_{5} Y=\frac{M_{o}}{-\Delta[\beta-\text { pinene }]}$

$M_{o}$ was calculated from the average of the measured mobility equivalent aerosol particle size distributions, assuming spherical particles and a particle density of $1.2 \mathrm{~g} \mathrm{~cm}^{-3}$ (Bahreini et al., 2005). For the determination of $-\Delta[\beta$-pinene $]$ we calculated the decrease of ozone concentration $\left(-\Delta\left[\mathrm{O}_{3}\right]\right)$ assuming pseudo-first order reaction kinetics based on a near-constant excess concentration of $\beta$-pinene $\left([\beta \text {-pinene }]_{0}\right)$ :

$-\Delta\left[O_{3}\right]=\left[O_{3}\right]_{0} \times\left(1-\exp \left(k_{O_{3}}[\beta \text {-pinene }]_{0} \Delta t\right)\right)$

Temperature-dependent reaction rate coefficients $\left(k_{O 3}\right)$ were calculated from the Arrhenius equation:

$k_{O 3}=A \exp \left(\frac{-E_{a}}{R T}\right)$

15 where $A=1.2 \times 10^{-15} \pm 4.6 \times 10^{-17} \mathrm{~cm}^{3}$ molecule ${ }^{-1} \mathrm{~s}^{-1}, E_{a} / R=1300 \pm 75 \mathrm{~K}$ (Khamaganov and Hites, 2001; Atkinson and Arey, 2003). The ozonolysis of $\beta$-pinene produces $\mathrm{OH}$ radicals with a stoichiometric yield $\left(\alpha_{O H}\right)$ of 0.35 at $296 \mathrm{~K}$ (Atkinson et al., 1992). No OH scavenger was used in this study to approach atmospherically relevant conditions and to avoid unwanted changes in the radical chemistry (Docherty and Ziemann, 2003). Under the assumptions that $\alpha_{\mathrm{OH}}$ is independent of temperature and that all $\mathrm{OH}$ radicals react with $\beta$-pinene $\left(k_{O H}=7.89 \times 10^{-11} \gg k_{O 3}=1.5 \times 10^{-17}\right.$ at $298 \mathrm{~K}$ (Atkinson, 1994)), we calculated $-\Delta[\beta$-pinene $]=1.35\left(-\Delta\left[\mathrm{O}_{3}\right]\right)$. SOA yield from $\mathrm{OH}$ reactions are negligible 10280

\section{Temperature dependence of SOA yield \\ C. Stenby et al.}

Title Page

Abstract

Introduction

Conclusions

References

Tables

Figures

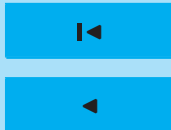

$\rightarrow$

Back

Close

Full Screen / Esc

Printer-friendly Version

Interactive Discussion 
compared to yield from ozonolysis (Bonn and Moortgat, 2002), thus this secondary loss of $\beta$-pinene reduces the yield. For the few experiments where $\left[O_{3}\right]_{0}$ was higher than $[\beta \text {-pinene }]_{0},-\Delta[\beta$-pinene $]$ was calculated from Eq. (2) interchanging $\beta$-pinene and ozone. The standard deviation of $M_{O}\left(s_{M o}\right)$ was calculated from the measurements 5 of the particle size distribution. Possible errors in the density of the particles have not been taken into account. The number of measured size distributions ( $n$ ) in each experiment is given in Table 1.

The standard deviation of the yield $\left(s_{Y}\right)$ is calculated by propagating $s_{M o}$ and the standard deviation of $-\Delta[\beta$-pinene $]\left(s_{-\Delta \beta}\right.$-pinene $)$ :

$s_{Y}=Y * \sqrt{\left(\frac{s_{M_{o}}}{M_{o}}\right)^{2}+\left(\frac{s_{-\Delta}[\beta-\text { pinene }]}{-\Delta[\beta-\text { pinene }]}\right)^{2}}$

$s_{-\Delta \beta-p i n e n e}$ is itself propagated from the standard deviations of $\alpha_{\mathrm{OH}},\left[\mathrm{O}_{3}\right]_{0},[\beta-$ pinene $]_{0}, \Delta t$ and $k_{O 3}$ :

$s_{-\Delta[\beta-\text { pinene }]}=(-\Delta[\beta-$ pinene $]) \times \sqrt{\left(\frac{s_{\alpha_{O H}}}{\alpha_{O H}}\right)^{2}+\left(\frac{s_{\left[O_{3}\right]_{0}}}{\left[O_{3}\right]_{0}}\right)^{2}+\left(\frac{s_{k O 3}}{k_{O 3}}\right)^{2}+\left(\frac{s_{\Delta t}}{\Delta t}\right)^{2}+\left(\frac{{ }^{s}[\beta-\text { pinene }]_{0}}{[\beta-\text { pinene }]_{0}}\right)^{2}}$

\subsection{Two-product model}

15 The ozonolysis of $\beta$-pinene leads to a large variety of products (Winterhalter et al., 2000), by lumping them into low-volatile and semi-volatile species, a two-product model can be used to simulate the SOA yield (Odum et al., 1996):

$Y=M_{o}\left(\frac{\alpha_{1} K_{o m, 1}}{R_{s, 1}+K_{o m, 1} M_{o}}+\frac{\alpha_{2} K_{o m, 2}}{R_{s, 2}+K_{o m, 2} M_{o}}\right)$

where $K_{o m, i}$ stands for the gas-particle partitioning coefficients, $\alpha_{i}$ is the stoichiometric yield, $R_{s, i}$ is the mass fraction of particulate matter that remains suspended in the gas;

\section{Temperature dependence of SOA yield \\ C. Stenby et al.}

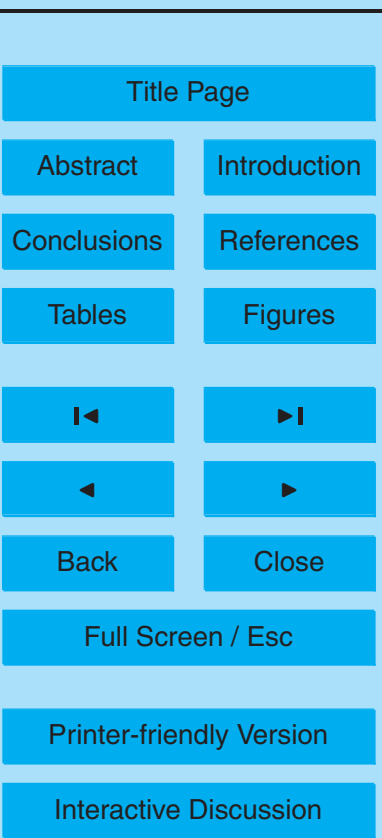


the counting variable i designates low volatile species (1) and semi-volatile species (2), respectively. During residence in the flow reactor the centrally sampled aerosol does not interact with the walls resulting in $R_{s, i}=1$. For any wall loss to occur the particles in the sample flow would have to be displaced $3.9 \mathrm{~cm}$ from the sampling orifice $(\mathrm{r}=1.1 \mathrm{~cm})$ 5 by Brownian diffusion. For the smallest particles in the size distribution ( $8 \mathrm{~nm}$ diameter) the probability for displacement larger than $0.27 \mathrm{~cm}$ is only $5 \%$ for the residence time of the sample flow (40 s). In smog chamber experiments the residence time is in the order of hours resulting in significant wall loss $\left(R_{s, i}<1\right)$.

\subsection{Fitting procedure}

10 Non-linear robust fits of Eq. (6) to the experimental data pairs of $M_{o}$ and $Y$ were performed. The input parameters $K_{o m, 1,303 K}$ and $K_{o m, 2,303 K}$ were varied from $0.001 \mathrm{~m}^{3} \mu \mathrm{g}^{-1}$ to $0.2 \mathrm{~m}^{3} \mu \mathrm{g}^{-1}$ with steps of $0.001 \mathrm{~m}^{3} \mu \mathrm{g}^{-1}$ with the premise that $K_{o m, 1,303 K}>K_{o m, 2,303 K}$. For the other temperatures $K_{o m, i, T}$ was then calculated as (Sheehan and Bowman, 2001):

$K_{o m, i, T}=K_{o m, i, 303 K} \frac{T}{303 K} \exp \left[B_{i}\left(\frac{1}{T}-\frac{1}{303 K}\right)\right]$

where

$B_{i}=\frac{\Delta_{v a p} H_{i}}{R} \approx \frac{\Delta_{v a p} S \times T_{b}}{R}$

$B$ values for the products from the $\beta$-pinene ozonolysis were calculated with the values for $\Delta_{v a p} S$ and $T_{b}$ reported by Jenkin (2004) and lumped as described by Bian and 20 Bowman (2002) to yield $B_{1}=6056 \mathrm{~K}$ and $B_{2}=5032 \mathrm{~K}$. Start values of $\alpha_{1}$ and $\alpha_{2}$ were determined by test calculations (Table 2), and for each temperature $\alpha_{1}$ and $\alpha_{2}$ were optimized with a Nelder-Mead algorithm to minimize the residual parameter $\mathrm{S}_{T}$ :

$S_{T}=\sum_{i} \frac{\left|Y_{\text {data }, T}-Y_{\text {model }, T}\right|_{i}}{S_{\text {data }, T, i}}$

\section{Temperature dependence of SOA yield \\ C. Stenby et al.}

Title Page

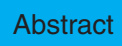

Introduction

Conclusions

References

Tables

Figures

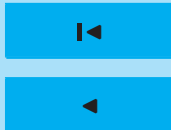

$\rightarrow 1$

Back

Close

Full Screen / Esc

Printer-friendly Version

Interactive Discussion 
Best fit values of $K_{o m, 1,303 K}$ and $K_{o m, 2,303 K}$ were taken at the minimum of the sum of residual parameters $\Sigma S_{T}$.

ACPD

6, 10275-10297, 2006

\section{Results and discussion}

SOA formation experiments have been performed at six different temperatures in the 5 range of $263-303 \mathrm{~K}$ as described in Sect. 2 . The SOA yields have been determined from the measured size distributions and calculated amounts of reacted $\beta$-pinene as described in Sect. 3.1, and the conditions and results of the individual experiments are listed in Table 1. Figure 2 displays exemplary particle size distributions and particle volume distributions of experiments performed with about 1.25 ppmv ozone and 1.2810 $\quad 1.37 \mathrm{ppmv} \beta$-pinene, except for the measurement at $293 \mathrm{~K}$ performed with $1.61 \mathrm{ppmv}$ $\beta$-pinene. The particle number concentration generally decreased with decreasing temperature, and the modal diameter increased.

The results of all experiments are summarized in Fig. 3, plotting the SOA yield against $M_{O}$. At all temperatures, the yield exhibits a near-linear increase with $M_{O}$ for ${ }_{15} M_{o}<10 \mu \mathrm{g} \mathrm{m}^{-3}$ and reaches a near-constant maximum level at $M_{o}>100 \mu \mathrm{g} \mathrm{m}^{-3}$. This behaviour can be described with the two-product model outlined in Sect. 3.2, which has been fitted to the data as described in Sect. 3.3.

The error bars depict the standard deviations for $M_{o}$ and SOA yield, calculated as described in Sect. 3.1. They illustrate that the relative standard deviations of repeated 20 measurements within one experiment were mostly $10 \%$ or less. The standard deviations between the SOA yield mean values obtained in different experiments repeated under near-identical conditions (similar $T$ and $\Delta$ [ $\beta$-pinene $]$ ) were generally less than 0.05 , corresponding to relative standard deviations up to $15 \%$. The standard deviation of the ozonolysis reaction rate coefficient $k_{\mathrm{O} 3}\left(s_{\mathrm{kO} 3}\right)$ is not included in the error bars of

25 Fig. 3. It varies only little over the investigated temperature range and does not affect the statistical uncertainty of our experimental data. It should, however, be taken into account when comparing the results to other studies and extrapolating to the atmo-

10283

\section{Temperature dependence of SOA yield \\ C. Stenby et al.}

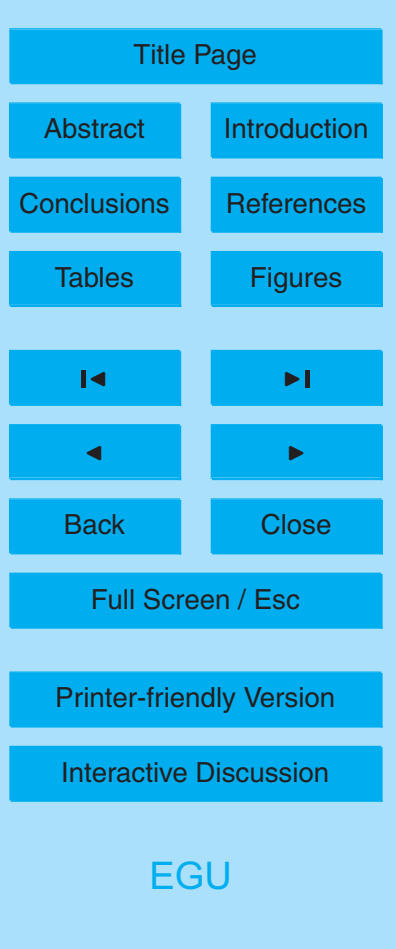


sphere. When $s_{k O 3}$ is included in Eq. (5), $s_{Y}$ is a factor of 2.0 to 2.7 higher than the error bars displayed in Fig. 3. This clearly demonstrates that a reduction of the uncertainty of $k_{O 3}$ will be of central importance for reducing uncertainties of SOA formation in atmospheric models.

5 Unexpectedly, the measured SOA yields do not exhibit a monotonous increase with decreasing temperature. Even if the statistical uncertainty of the measurement results is taken into account, the yields observed at $263 \mathrm{~K}$ were generally lower than those at $273 \mathrm{~K}$ and $278 \mathrm{~K}$ (most evident at $M_{o}>30 \mu \mathrm{g} / \mathrm{m}^{3}$; Fig. 3) and the ones observed at $283 \mathrm{~K}$ were lower than those at $263 \mathrm{~K}$ and $293 \mathrm{~K}$ (Fig. 3). This complex, non-linear 10 behaviour will be discussed below.

With the $\alpha_{i}$ starting values summarized in Table 2 and $B_{i}$ values fixed to $B_{1}=6056 \mathrm{~K}$ and $B_{2}=5032 \mathrm{~K}$ we have obtained the best-fit with $K_{o m, 1,303 K}=0.039 \mathrm{~m}^{3} \mu \mathrm{g}^{-1}$ and $K_{o m, 2,303 K}=0.001 \mathrm{~m}^{3} \mu \mathrm{g}^{-1}$. All other $K_{o m}$ values are calculated from Eq. (7) and listed in Table 3 together with the other best-fit parameters.

15 Up to now, only very few studies on the aerosol yield of $\beta$-pinene ozonolysis have been published, and to our knowledge only two of them report the parameters for a one or two product model (Table 3). As illustrated in Fig. 3, the maximum yield from the study by Hoffmann et al. (1997) at $292 \mathrm{~K}$ (open diamonds) agrees well with the maximum yield from our study at $293 \mathrm{~K}$ (filled diamonds). Note, however, that Hoffmann 20 et al. (1997) used a particle density of $1 \mathrm{~g} \mathrm{~cm}^{-3}$ whereas we use $1.2 \mathrm{~g} \mathrm{~cm}^{-3}$, meaning that we observed $20 \%$ less particle volume. A possible explanation is that the SOA particles in our flow tube experiments were freshly formed (40 s), whereas the study by Hoffmann et al. (1997) was done in a static chamber where the particles are subject to aging (typically $4 \mathrm{~h}$ ). Another explanation could be that Hoffmann et al. (1997) mea25 sured $-\Delta[\beta$-pinene], whereas it has been calculated in this study, being a subject to the large uncertainty of $k_{O 3}$. The chamber study by Griffin et al. (1999) at 303-308 K comprises only four data points with $M_{o}<30 \mu \mathrm{g} \mathrm{m}^{-3}$ and $Y<6 \%$ (Fig. 3, open triangles). A possible explanation for their much lower yields is that an $\mathrm{OH}$ scavenger (2-butanol) was used, which later has been shown to reduce yield from $\beta$-pinene ozonolysis sub-

\section{Temperature dependence of SOA yield \\ C. Stenby et al.}

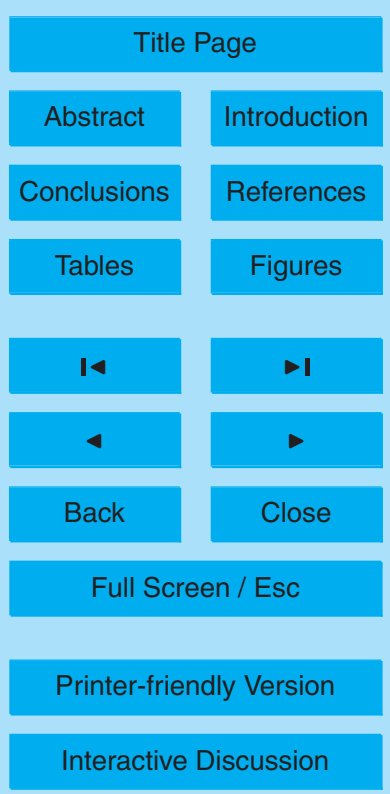

EGU 
stantially (Docherty and Ziemann, 2003). Nevertheless, the two-product model fit of Griffin et al. (1999) would have predicted a much higher maximum yield than observed in our measurements (Fig. 3).

Figure 4 illustrates the temperature dependence of SOA yields at $M_{o}=10 \mu \mathrm{g} \mathrm{m}^{-3}$ (a) 5 and $M_{o}=250 \mu \mathrm{g} \mathrm{m}^{-3}$ (b) as observed and modelled in our study and other investigations. At large, the results of our and other experiments are consistent with an overall trend of increasing SOA yield with decreasing temperature, as suggested by the model calculations of Jenkin (2004).

At the atmospherically relevant particle mass concentration level of $10 \mu \mathrm{g} \mathrm{m}^{-3}$ and in 10 the temperature range of $308-292 \mathrm{~K}$ our measurement results agree to within $18 \%$ with the model results of Jenkin (2004) and the measurement of Yu et al. (1999) (306 K), whereas the results of Griffin et al. (1999) is $57 \%$ lower and that of Hoffmann et al. (1997) is $43 \%$ higher. At $283-273 \mathrm{~K}$ our measurements deviate by up to $49 \%$ from the model of Jenkin (2004) (lower at $283 \mathrm{~K}$, higher at 273 and $278 \mathrm{~K}$ ), but at $263 \mathrm{~K}$ 15 they agree again to within $7 \%$.

At $M_{O}=250 \mu \mathrm{g} \mathrm{m}^{-3}$ (near-constant maximum level of SOA yield) the two product model extrapolations based on the measurements of Griffin et al. (1999) agree to within $12 \%$ with the model of Jenkin (2004). The yields reported by Jaoui and Kamens (2003) from experiments in the presence of water vapor $(\mathrm{RH}=40-55 \%)$ agreed to within $4 \%$ 20 at $290-285 \mathrm{~K}$ with the model of Jenkin (2004), but they were $40 \%$ lower at 304-297 K. At 303,283 , and $263 \mathrm{~K}$ our measurement results agree to within $14 \%$ with the model of Jenkin (2004). At 293, 278, and $273 \mathrm{~K}$, however, our measurement results as well as that of Hoffmann et al. (1997) are $29-51 \%$ higher.

As pointed out above (discussion of Fig. 3), the deviations of the SOA yields ob25 served in our experiments from the expected monotonous temperature dependence (linear increase with with inverse $T$, Fig. 4), exceed the statistical uncertainty of our measurements. Possible explanations will be explored and discussed below. If, however, a linear fit is applied to our data plotted against inverse $T$ (dashed red line in Fig. 4), the slopes are of similar magnitude as predicted by Jenkin (2004). At

\section{Temperature dependence of SOA yield \\ C. Stenby et al.}

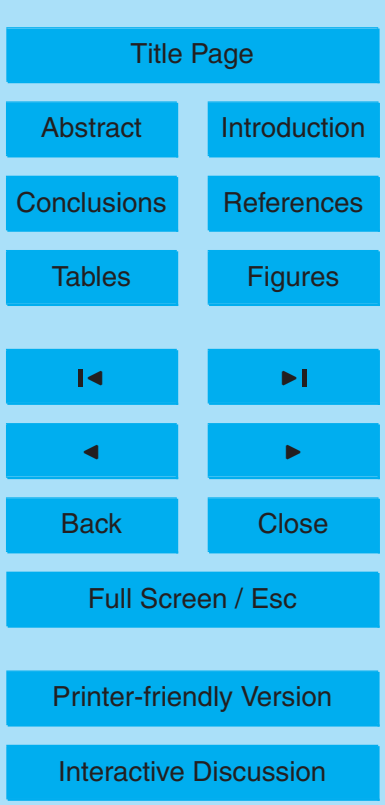


$M_{o}=10 \mu \mathrm{g} \mathrm{m}^{-3}$ the fit to the measurement data is $\sim 50 \%$ steeper than the model prediction by Jenkin (2004) ( $277 \mathrm{~K}$ vs. $186 \mathrm{~K}$ ); at $M_{o}=250 \mu \mathrm{g} \mathrm{m}^{-3}$ it is $\sim 40 \%$ less steep $(108 \mathrm{~K}$ vs. $179 \mathrm{~K}$ ). Moreover, the steeper slope at lower particle mass concentration ( $277 \mathrm{~K}$ vs. $108 \mathrm{~K}$ ) is consistent with the model prediction that for lower temperatures the maximum 5 yield should be reached at lower $M_{0}$.

In the model of Jenkin (2004) as well as in other models recently developed to predict SOA yields (Cocker et al., 2001; Kamens and Jaoui, 2001; Bian and Bowman, 2002), a wide variety gas-phase reaction products are lumped on the basis of their vapour pressures, and representative $\alpha_{i}, K_{o m, i}$ and $B_{i}$ values are calculated for each 10 lumped species. $K_{o m, i}$ values calculated on the basis of atmospheric gas phase chemistry mechanisms are generally much lower than the $K_{o m, i}$ values obtained by fitting to SOA measurements, which have been attributed to association reactions of organics in the aerosol phase (Tobias and Ziemann, 2000; Kamens and Jaoui, 2001). Accordingly, Jenkin (2004) applied a scaling factor of 120 to the $K_{o m, i}$ values calculated for 15 SOA formation from $\beta$-pinene ozonolysis. As illustrated in Fig. 4 , this and other models usually exhibit a linear dependence of SOA yield on inverse temperature. The linear dependence is a consequence of assigning a Clausius-Clapeyron-type temperature dependence to the gas-particle partitioning coefficients $K_{o m, i}$ and assuming no temperature dependence of the stoichiometric yields $\alpha_{i}$.

20 To reproduce the SOA yields measured in our study, however, it is necessary to allow a temperature dependence of $\alpha_{i}$ (Table 3), which implies that the product yields, i.e. the amounts of low-volatile and semi-volatile species produced, change with temperature. The formation of condensable species from volatile precursor gases involve numerous reaction steps and intermediates (Jenkin, 2004), and a combination of exothermal and 25 endothermal processes may well lead to complex temperature dependencies as observed in our experiments. As pointed out above, SOA formation is likely to involve not only gas phase but also condensed phase reactions such as the formation of secondgeneration oxidation products or oligomers. Contrary to gas-particle partitioning, which is expected to decrease the SOA yield with increasing temperature (decrease of $K_{o m, i}$
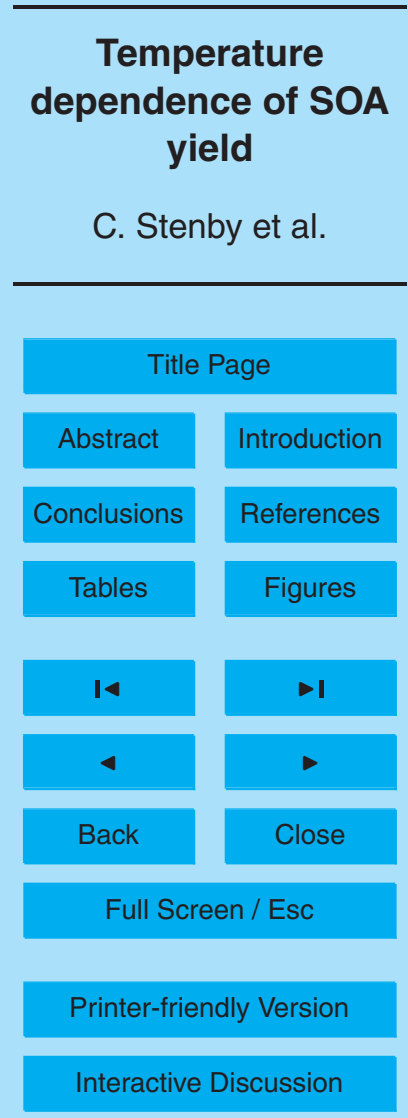
with increasing $T$ ), the chemical reactions leading to second-generation products with lower volatility are likely to be accelerated at higher temperatures.

This work demonstrates the need for further investigations and mechanistic elucidation of the complex physico-chemical processes involved in atmospheric particle for5 mation and gas-particle interactions (multiphase chemical reactions, mass transport, and phase transitions (Pöschl et al., 2005; Fuzzi et al., 2006).

\section{Conclusions}

Organic carbon aerosol concentrations measured in the free troposphere are between 10 and 100 times higher than the concentrations modelled by a state of the art global chemical transport model (Heald et al., 2005). Our study with $\beta$-pinene as a model compound shows that insufficient description of the temperature dependence of SOA formation may explain some of these discrepancies. The results of fitting with a twoproduct model indicate that not only the reaction product vapour pressures but also the relative contributions of different gas-phase or multiphase reaction channels are depen15 dent on temperature. The results demonstrate that further investigations are needed for mechanistic elucidation and reliable description of the complex physico-chemical processes involved in SOA formation. The influence of temperature should be considered not only for gas-particle partitioning of VOC oxidation products but also for the pathways and kinetics of gas phase and multiphase chemical reactions of VOC, semivolatile, and low-volatile organic species. In atmospheric models both the temperature of oxidative processing and the local temperature of gas-particle partitioning should be taken into account for the modelling of SOA. Differences between these temperatures and their effects could be particularly important in the tropics, where high BVOC emissions and high oxidizing capacities can lead to large amounts of low-volatile and altitudes where low temperatures favour condensation.

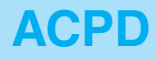

6, 10275-10297, 2006

\section{Temperature dependence of SOA yield \\ C. Stenby et al.}

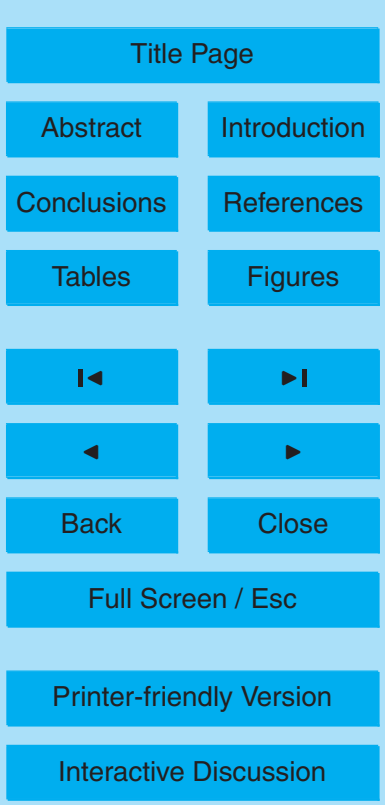


Acknowledgements. O. J. Nielsen and M. Bilde acknowledge financial support from the Danish Natural Science Research Council. The authors would like to thank G. Schuster for his technical expertise and support of the experimental work. Thanks to B. Svensmark, T. Hoffmann and J. Curtius for helpful discussions.

\section{References}

Atkinson, R.: Gas-phase tropospheric chemistry of organic compounds, J. Phys. Chem. Ref. Data, 2, 1-216, 1994.

Atkinson, R. and Arey, J.: Atmospheric degradation of volatile organic compounds, Chem. Rev., 103, 4605-4638, 2003.

Atkinson, R., Aschmann, S. M., Arey, J., and Shorees, B.: Formation of OH radicals in the gas phase reactions of $\mathrm{O}_{3}$ with a series of terpenes, J. Geophys. Res., 97, 6065-6073, 1992.

Bahreini, R., Keywood, M. D., Ng, N. L., Varutbangkul, V., Gao, S., Flagan, R. C., Seinfeld, J. H., Worsnop, D. R., and Jimenez, J. L.: Measurements of secondary organic aerosol from oxidation of cycloalkenes, terpenes, and m-xylene using an Aerodyne aerosol mass 15 spectrometer, Environ. Sci. Technol., 39, 5674-5688, 2005.

Bian, F. and Bowman, F. M.: Theoretical method for lumping multicomponent secondary organic aerosol mixtures, Environ. Sci. Technol., 36, 2491-2497, 2002.

Bonn, B. and Moortgat, G. K.: New particle formation during $\alpha$ - and $\beta$-pinene oxidation by $\mathrm{O}_{3}$, $\mathrm{OH}$ and $\mathrm{NO}_{3}$, and the influence of water vapour: particle size distribution studies, Atmos. Chem. Phys., 2, 183-196, 2002.

Bonn, B., Schuster, G., and Moortgat, G. K.: Influence of water vapor on the process of new particle formation during monoterpene ozonolysis, J. Phys. Chem. A, 106, 2869-2881, 2002.

Chung, S. H. and Seinfeld, J. H.: Global distribution and climate forcing of carbonaceous aerosols, J. Geophys. Res., 107, 4407, doi:10.1029/2001JD001397, 2002.

25 Cocker, D. R., Clegg, S. L., Flagan, R. C., and Seinfeld, J. H.: The effect of water on gasparticle partitioning of secondary organic aerosol. Part I: alpha-pinene/ozone system, Atmos. Environ., 35, 6049-6072, 2001.

Docherty, K. S. and Ziemann, P. J.: Effects of stabilized Criegee intermediate and $\mathrm{OH}$ radical scavengers on aerosol formation from reactions of beta-pinene with 0-3, Aerosol Sci. Technol., 37, 877-891, 2003.

\section{Temperature dependence of SOA yield \\ C. Stenby et al.}

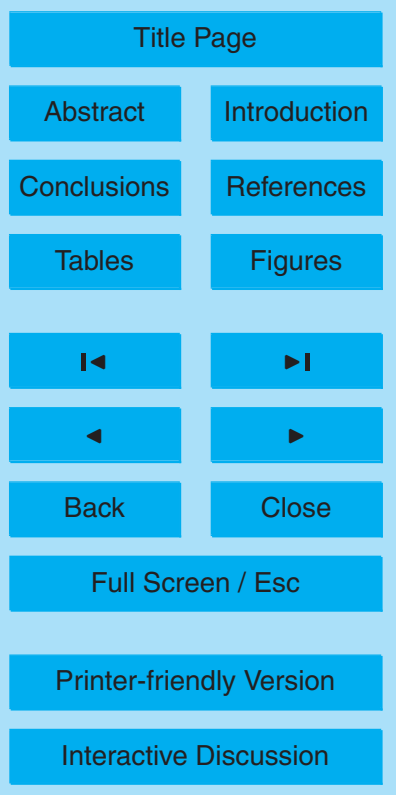


Fuzzi, S., Andreae, M. O., Huebert, B. J., Kulmala, M., Bond, T. C., Boy, M., Doherty, S. J., Guenther, A., Kanakidou, M., Kawamura, K., Kerminen, V.-M., Lohmann, U., Russell, L. M., and Pöschl, U.: Critical assessment of the current state of scientific knowledge, terminology, and research needs concerning the role of organic aerosols in the atmosphere, climate, and 5 global change, Atmos. Chem. Phys., 6, 2017-2038, 2006.

Griffin, R. J., Cocker, D. R., Flagan, R. C., and Seinfeld, J. H.: Organic aerosol formation from the oxidation of biogenic hydrocarbons, J. Geophys. Res., 104, 3555-3567, 1999.

Hartz, K. E. H., Rosenorn, T., Ferchak, S. R., Raymond, T. M., Bilde, M., Donahue, N. M., and Pandis, S. N.: Cloud condensation nuclei activation of monoterpene and sesquiterpene secondary organic aerosol, J. Geophys. Res., 110, D14208, doi:10.1029/2004JD005754, 2005.

Heald, C. L., Jacob, D. J., Park, R. J., Russell, L. M., Huebert, B. J., Seinfeld, J. H., Liao, H., and Weber, R. J.: A large organic aerosol source in the free troposphere missing from current models, Geophys. Res. Lett., 32, L18809, doi:10.1029/2005GL023831, 2005.

Hoffmann, T., Odum, J., Bowman, F., Collins, D., Klockow, D., Flagan, R. C., and Seinfeld, J. $\mathrm{H}$.: Formation of organic aerosols from the oxidation of biogenic hydrocarbons, J. Atmos. Chem., 26, 189-222, 1997.

Jenkin, M. E.: Modelling the formation and composition of secondary organic aerosol from alpha- and beta-pinene ozonolysis using MCM v3, Atmos. Chem. Phys., 4, 1741-1757, 2004.

Kamens, R. M. and Jaoui, M.: Modeling aerosol formation from alpha-pinene plus NOx in the presence of natural sunlight using gas-phase kinetics and gas-particle partitioning theory, Environ. Sci. Technol., 35, 1394-1405, 2001.

Kanakidou, M., Seinfeld, J. H., Pandis, S. N., Barnes, I., Dentener, F. J., Facchini, M. C., Van Dingenen, R., Ervens, B., Nenes, A., Nielsen, C. J., Swietlicki, E., Putaud, J. P., Balkanski, Y., Fuzzi, S., Horth, J., Moortgat, G. K., Winterhalter, R., Myhre, C. E. L., Tsigaridis, K., Vignati, E., Stephanou, E. G., and Wilson, J.: Organic aerosol and global climate modelling: a review, Atmos. Chem. Phys., 5, 1053-1123, 2005.

Khamaganov, V. G. and Hites, R. A.: Rate constants for the gas-phase reactions of ozone with isoprene, alpha- and beta-pinene, and limonene as a function of temperature, J. Phys. Chem. A, 105, 815-822, 2001.

Odum, J. R., Hoffmann, T., Bowman, F., Collins, D., Flagan, R. C., and Seinfeld, J. H.: Gas/particle partitioning and secondary organic aerosol formation, Environ. Sci. Technol.,

\section{Temperature dependence of SOA yield}

C. Stenby et al.

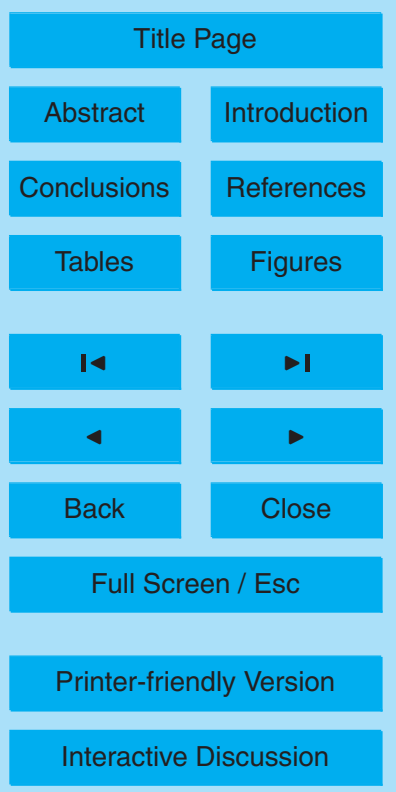


30, 2580-2585, 1996.

Pöschl, U., Rudich, Y., and Ammann, M.: Kinetic model framework for aerosol and cloud surface chemistry and gas-particle interactions: Part 1 - general equations, parameters, and terminology, Atmos. Chem. Phys. Discuss., 5, 2111-2191, 2005.

5 Sheehan, P. E. and Bowman, F. M.: Estimated effects of temperature on secondary organic aerosol concentrations, Environ. Sci. Technol., 35, 2129-2135, 2001.

Takekawa, H., Minoura, H., and Yamazaki, S.: Temperature dependence of secondary organic aerosol formation by photo-oxidation of hydrocarbons, Atmos. Environ., 37, 34133424, 2003.

10 Tobias, H. J. and Ziemann, P. J.: Thermal desorption mass spectrometric analysis of organic aerosol formed from reactions of 1-tetradecene and $\mathrm{O}_{3}$ in the presence of alcohols and carboxylic acids, Environ. Sci. Technol., 34, 2105-2115, 2000.

Tsigaridis, K. and Kanakidou, M.: Global modelling of secondary organic aerosol in the troposphere: a sensitivity analysis, Atmos. Chem. Phys., 3, 1849-1869, 2003.

15 VanReken, T. M., Ng, N. L., Flagan, R. C., and Seinfeld, J. H.: Cloud condensation nucleus activation properties of biogenic secondary organic aerosol, J. Geophys. Res., 110, D07206, doi:10.1029/2004JD005465, 2005.

Wiedinmyer, C., Guenther, A., Harley, P., Hewitt, N., Geron, C., Artaxo, P., Steinbrecher, R., and Rasmussen, R.: Global organic emissions from vegetation, in: Emissions of atmospheric trace compounds, vol. 18, edited by: Granier, C., Artaxo, P., and Reeves, C. E., Kluwer Academic Publishers, Dordrecht, The Netherlands, pp. 115-170, 2004.

Winterhalter, R., Neeb, P., Grossmann, D., Kolloff, A., Horie, O., and Moortgat, G.: Products and mechanism of the gas phase reaction of ozone with $\beta$-pinene, J. Atmos. Chem., 35, 165-197, 2000.

25 Yu, J. Z., Cocker, D. R., Griffin, R. J., Flagan, R. C., and Seinfeld, J. H.: Gas-phase ozone oxidation of monoterpenes: Gaseous and particulate products, J. Atmos. Chem., 34, 207258, 1999.

\section{Temperature dependence of SOA yield}

C. Stenby et al.

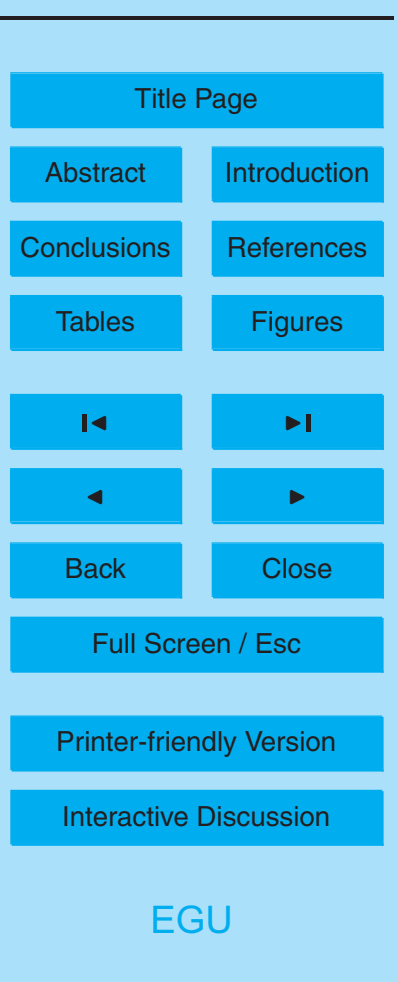


Table 1. Conditions and results of individual experiments: $-\Delta \beta$-pinene $=$ decrease of $\beta$ pinene mass concentration, $\mathrm{N}=$ total particle number concentration, $M_{o}=$ total particle mass concentration, $\mathrm{s}_{M o}=$ standard deviation of $M_{o}, Y=\mathrm{SOA}$ yield, $\mathrm{s}_{y}=$ standard deviation of $Y, \mathrm{n}$ $=$ number of measured particle size distribution in each experiment, Sheath = sheath air flow, $\Delta t=40$ s.

\begin{tabular}{|c|c|c|c|c|c|c|c|c|c|c|c|}
\hline & $\begin{array}{l}T \\
\mathrm{~K}\end{array}$ & $\begin{array}{l}{[\beta \text {-pinene }]} \\
\text { ppbv }\end{array}$ & $\begin{array}{l}\text { [ozone] } \\
\text { ppbv }\end{array}$ & $\begin{array}{l}-\Delta \beta \text {-pinene } \\
\mu \mathrm{g} \mathrm{m}^{-3}\end{array}$ & $\begin{array}{l}\mathrm{N} \\
\# \mathrm{~cm}^{-3}\end{array}$ & $\begin{array}{l}M_{o} \\
\mu \mathrm{g} \mathrm{m}^{-3}\end{array}$ & $\begin{array}{l}\mathrm{s}_{M o} \\
\mu \mathrm{g} \mathrm{m}^{-3}\end{array}$ & $Y$ & $\mathrm{~s}_{Y}$ & $n$ & $\begin{array}{l}\text { Sheath } \\
I \min ^{-1}\end{array}$ \\
\hline bp240106_6 & 263 & 601 & 1031 & 49.5 & $5.5 \mathrm{E}+05$ & 9.3 & 0.48 & 0.19 & 0.02 & 5 & 3.0 \\
\hline bp240106_5 & 263 & 601 & 1362 & 65.2 & $7.5 \mathrm{E}+05$ & 12.6 & 0.74 & 0.19 & 0.02 & 11 & 3.0 \\
\hline bp240106_4 & 263 & 754 & 1937 & 116.2 & $1.3 \mathrm{E}+06$ & 27.2 & 1.59 & 0.23 & 0.02 & 12 & 3.0 \\
\hline bp100106_3 & 263 & 2893 & 623 & 142.6 & $1.9 \mathrm{E}+06$ & 30.9 & 2.17 & 0.22 & 0.02 & 11 & 9.7 \\
\hline bp240106_3 & 263 & 3024 & 1934 & 462.6 & $3.3 \mathrm{E}+06$ & 123.9 & 5.80 & 0.27 & 0.02 & 5 & 3.0 \\
\hline bp240106_1 & 263 & 3031 & 1964 & 470.8 & 3.1E+06 & 120.8 & 6.44 & 0.26 & 0.02 & 23 & 3.0 \\
\hline bp100106_2 & 263 & 5705 & 1126 & 501.7 & 3. $4 \mathrm{E}+06$ & 121.0 & 8.27 & 0.24 & 0.02 & 15 & 9.7 \\
\hline bp240106_2 & 263 & 5977 & 1991 & 928.5 & 4.4E+06 & 245.6 & 7.35 & 0.26 & 0.02 & 9 & 3.0 \\
\hline bp170106_3 & 273 & 754 & 669 & 44.9 & 3. $4 \mathrm{E}+05$ & 10.1 & 0.56 & 0.23 & 0.02 & 13 & 9.7 \\
\hline bp170106_4 & 273 & 754 & 1190 & 79.6 & $9.7 \mathrm{E}+05$ & 23.8 & 1.74 & 0.30 & 0.03 & 13 & 6.0 \\
\hline bp040106_2 & 273 & 5991 & 376 & 194.6 & $2.5 \mathrm{E}+06$ & 60.6 & 3.11 & 0.31 & 0.02 & 9 & 9.7 \\
\hline bp170106_5 & 273 & 3151 & 1182 & 326.7 & $3.9 \mathrm{E}+06$ & 120.7 & 8.48 & 0.37 & 0.03 & 12 & 6.0 \\
\hline bp170106_2 & 273 & 6204 & 1188 & 635.8 & $4.2 \mathrm{E}+06$ & 241.3 & 7.81 & 0.38 & 0.03 & 11 & 9.7 \\
\hline bp220506_5 & 278 & 599 & 545 & 30.5 & $4.2 \mathrm{E}+05$ & 6.0 & 0.51 & 0.20 & 0.02 & 7 & 9.7 \\
\hline bp220506_2 & 278 & 783 & 721 & 52.7 & $7.5 \mathrm{E}+05$ & 10.6 & 1.13 & 0.20 & 0.02 & 22 & 9.7 \\
\hline bp220506_1 & 278 & 1375 & 1249 & 159.6 & $2.3 \mathrm{E}+06$ & 44.1 & 4.75 & 0.28 & 0.03 & 24 & 9.7 \\
\hline bp220506_4 & 278 & 2003 & 1815 & 336.9 & $4.1 \mathrm{E}+06$ & 114.6 & 11.90 & 0.34 & 0.04 & 15 & 9.7 \\
\hline bp220506_3 & 278 & 2782 & 2380 & 611.0 & $5.1 \mathrm{E}+06$ & 238.9 & 18.49 & 0.39 & 0.04 & 20 & 9.7 \\
\hline bp270106_1 & 283 & 1565 & 437 & 66.6 & $4.5 \mathrm{E}+05$ & 2.0 & 0.04 & 0.03 & 0.00 & 10 & 3.0 \\
\hline bp150306_1 & 283 & 1500 & 651 & 95.1 & $1.2 \mathrm{E}+06$ & 7.2 & 0.06 & 0.08 & 0.00 & 12 & 9.7 \\
\hline bp150306_2a & 283 & 1506 & 797 & 116.8 & $1.9 \mathrm{E}+06$ & 11.5 & 0.07 & 0.10 & 0.01 & 11 & 9.7 \\
\hline bp160306_1a & 283 & 1363 & 1266 & 168.2 & 2.7E+06 & 25.2 & 0.29 & 0.15 & 0.01 & 17 & 9.7 \\
\hline bp270106_2 & 283 & 1565 & 1262 & 192.3 & $2.4 \mathrm{E}+06$ & 21.7 & 0.38 & 0.11 & 0.01 & 16 & 3.0 \\
\hline bp230106_6 & 283 & 1630 & 2086 & 329.9 & 3. $6 \mathrm{E}+06$ & 52.7 & 0.70 & 0.16 & 0.01 & 12 & 3.0 \\
\hline bp230106_5 & 283 & 3253 & 2073 & 649.3 & $5.2 \mathrm{E}+06$ & 124.4 & 0.80 & 0.19 & 0.01 & 10 & 3.0 \\
\hline bp230106_1 & 283 & 6431 & 1233 & 748.8 & $4.8 \mathrm{E}+06$ & 124.6 & 1.38 & 0.17 & 0.01 & 13 & 9.7 \\
\hline bp230106_3 & 283 & 6430 & 1254 & 761.5 & $5.5 \mathrm{E}+06$ & 143.7 & 1.56 & 0.19 & 0.01 & 8 & 3.0 \\
\hline bp230106_2 & 283 & 6432 & 1288 & 782.3 & $5.1 \mathrm{E}+06$ & 147.8 & 2.01 & 0.19 & 0.01 & 11 & 9.7 \\
\hline bp230106_4 & 283 & 6430 & 2097 & 1273.1 & $6.6 \mathrm{E}+06$ & 280.1 & 1.76 & 0.22 & 0.01 & 9 & 3.0 \\
\hline bp140106_3 & 293 & 774 & 1280 & 105.3 & $2.2 \mathrm{E}+06$ & 15.9 & 0.54 & 0.15 & 0.01 & 4 & 9.7 \\
\hline bp191205_4 & 293 & 5444 & 199 & 111.9 & 2.4E+06 & 20.5 & 0.26 & 0.18 & 0.01 & 10 & 5.0 \\
\hline bp130106_1 & 293 & 1611 & 658 & 112.4 & 2. $6 \mathrm{E}+06$ & 23.6 & 0.17 & 0.21 & 0.01 & 11 & 9.7 \\
\hline bp140106_1 & 293 & 1611 & 1255 & 214.4 & 3.7E+06 & 56.9 & 0.79 & 0.27 & 0.02 & 10 & 9.7 \\
\hline bp191205_1 & 293 & 5443 & 415 & 233.1 & $3.5 \mathrm{E}+06$ & 53.8 & 0.78 & 0.23 & 0.01 & 10 & 5.0 \\
\hline bp191205_2 & 293 & 5453 & 793 & 446.1 & 4.7E+06 & 131.3 & 1.65 & 0.29 & 0.02 & 10 & 5.0 \\
\hline bp140106_2 & 293 & 6364 & 1269 & 828.4 & $5.8 \mathrm{E}+06$ & 283.6 & 3.23 & 0.34 & 0.02 & 4 & 9.7 \\
\hline bp191205_3 & 293 & 10863 & 790 & 853.2 & $5.7 \mathrm{E}+06$ & 274.9 & 3.45 & 0.32 & 0.02 & 8 & 5.0 \\
\hline bp210306_2 & 303 & 851 & 1309 & 128.0 & 1.1E+06 & 7.4 & 0.16 & 0.06 & 0.00 & 17 & 9.7 \\
\hline bp201205_2 & 303 & 6682 & 215 & 158.0 & $1.6 \mathrm{E}+06$ & 15.9 & 0.50 & 0.10 & 0.01 & 8 & 9.7 \\
\hline bp210306_1 & 303 & 1361 & 1261 & 197.1 & 2.7E+06 & 37.0 & 0.82 & 0.19 & 0.01 & 16 & 9.7 \\
\hline bp201205_3 & 303 & 6671 & 431 & 316.8 & 3.4E+06 & 64.0 & 0.82 & 0.20 & 0.01 & 22 & 9.7 \\
\hline bp201205_1 & 303 & 6677 & 846 & 622.2 & 4.3E+06 & 135.3 & 2.54 & 0.22 & 0.01 & 8 & 9.7 \\
\hline bp201205_4 & 303 & 10014 & 842 & 905.9 & $5.0 \mathrm{E}+06$ & 205.2 & 4.21 & 0.23 & 0.01 & 10 & 9.7 \\
\hline
\end{tabular}

ACPD

6, 10275-10297, 2006

\section{Temperature dependence of SOA yield \\ C. Stenby et al.}

Title Page

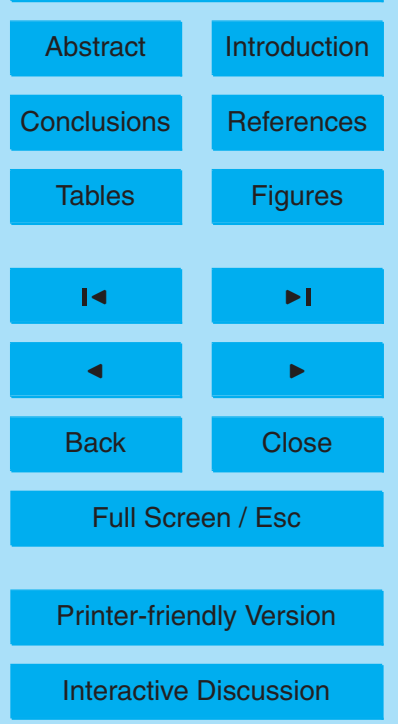




\section{ACPD}

6, 10275-10297, 2006

\section{Temperature dependence of SOA yield \\ C. Stenby et al.}

Table 2. Start values for the two product model fit: $\alpha_{1}$ and $\alpha_{2}$ are the stoichiometric yields of the low volatile and semi volatile species.

\begin{tabular}{ccc}
\hline$T(\mathrm{~K})$ & $\alpha_{1}$ & $\alpha_{2}$ \\
\hline 263 & 0.10 & 0.17 \\
273 & 0.09 & 0.29 \\
278 & 0.10 & 0.30 \\
283 & 0.03 & 0.18 \\
293 & 0.01 & 0.33 \\
303 & 0.08 & 0.16 \\
\hline
\end{tabular}

Title Page

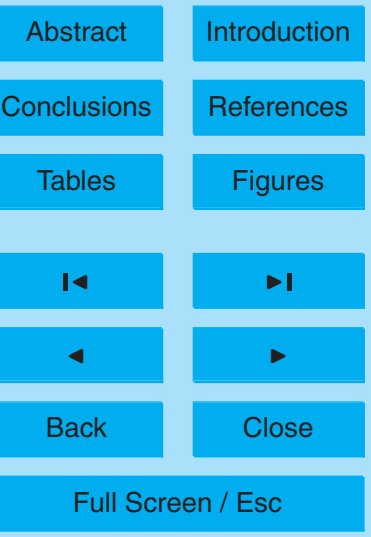

Printer-friendly Version

Interactive Discussion 


\section{ACPD}

6, 10275-10297, 2006

Table 3. Best-fit values of the two product model fits from our study and the fit parameters from two other studies. For our study $B_{1}=6056 \mathrm{~K}$ and $B_{2}=5032 \mathrm{~K}$ (Fig. 3). $K_{o m, i}=$ partitioning coefficient, $\alpha_{i}=$ stoichiometric yield, $\mathrm{S}_{T}=$ optimised residual parameter (Sect. 3.3), $\mathrm{n}=$ number of data points (experiments).

\begin{tabular}{lllllll}
\hline$T(\mathrm{~K})$ & $K_{o m, 1}\left(\mathrm{~m}^{3} \mu \mathrm{g}^{-1}\right)$ & $K_{o m, 2}\left(\mathrm{~m}^{3} \mu \mathrm{g}^{-1}\right)$ & $\alpha_{1}$ & $\alpha_{2}$ & $\mathrm{~S}_{T}$ & $\mathrm{n}$ \\
\hline 263 & 0.708 & 0.011 & 0.208 & 0.079 & 2.75 & 8 \\
273 & 0.316 & 0.006 & 0.285 & 0.172 & 1.73 & 5 \\
278 & 0.216 & 0.004 & 0.274 & 0.247 & 2.12 & 5 \\
283 & 0.150 & 0.003 & 0.139 & 0.184 & 9.33 & 11 \\
293 & 0.075 & 0.002 & 0.295 & 0.145 & 3.23 & 8 \\
303 & 0.039 & 0.001 & 0.259 & 0 & 4.71 & 6 \\
$292^{\mathrm{a}}$ & 0.11 & - & 0.35 & - & & \\
$305^{\mathrm{b}}$ & 0.195 & 0.003 & 0.026 & 0.485 & & \\
\hline
\end{tabular}

\section{Temperature dependence of SOA yield \\ C. Stenby et al.}

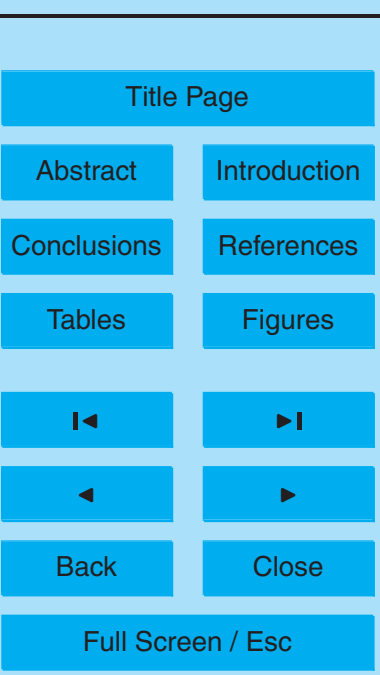

Printer-friendly Version

a Hoffmann et al. (1997)

${ }^{b}$ Griffin et al. (1999) 


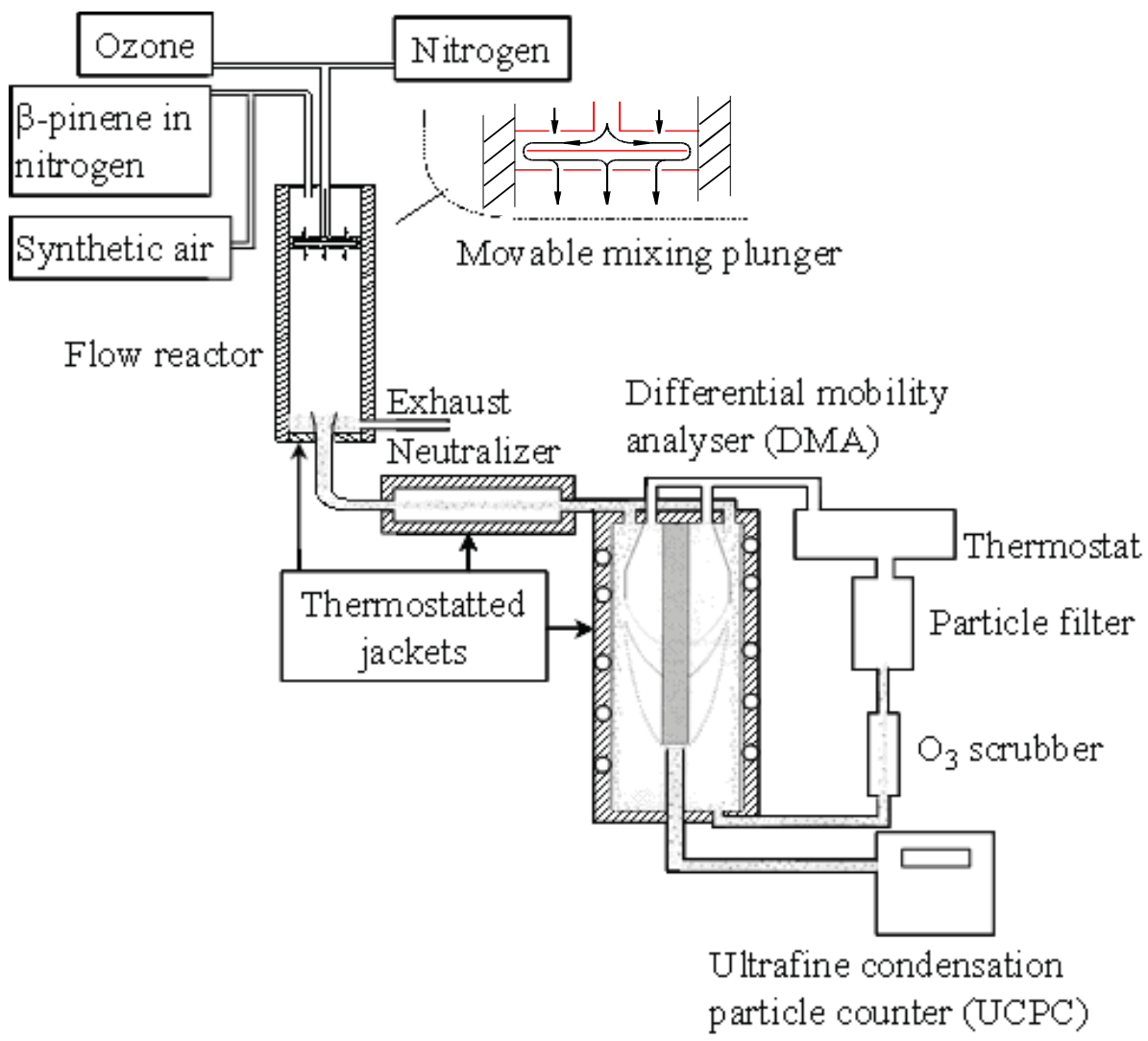

6, 10275-10297, 2006

\section{Temperature dependence of SOA yield \\ C. Stenby et al.}

Title Page

Abstract

Conclusions

Tables

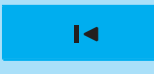

4

Back
Introduction

References

Figures

$\rightarrow$

$>$

Close

Full Screen / Esc

Printer-friendly Version

Interactive Discussion

Fig. 1. Schematic drawing of the experimental set-up. 


\section{ACPD}

6, 10275-10297, 2006
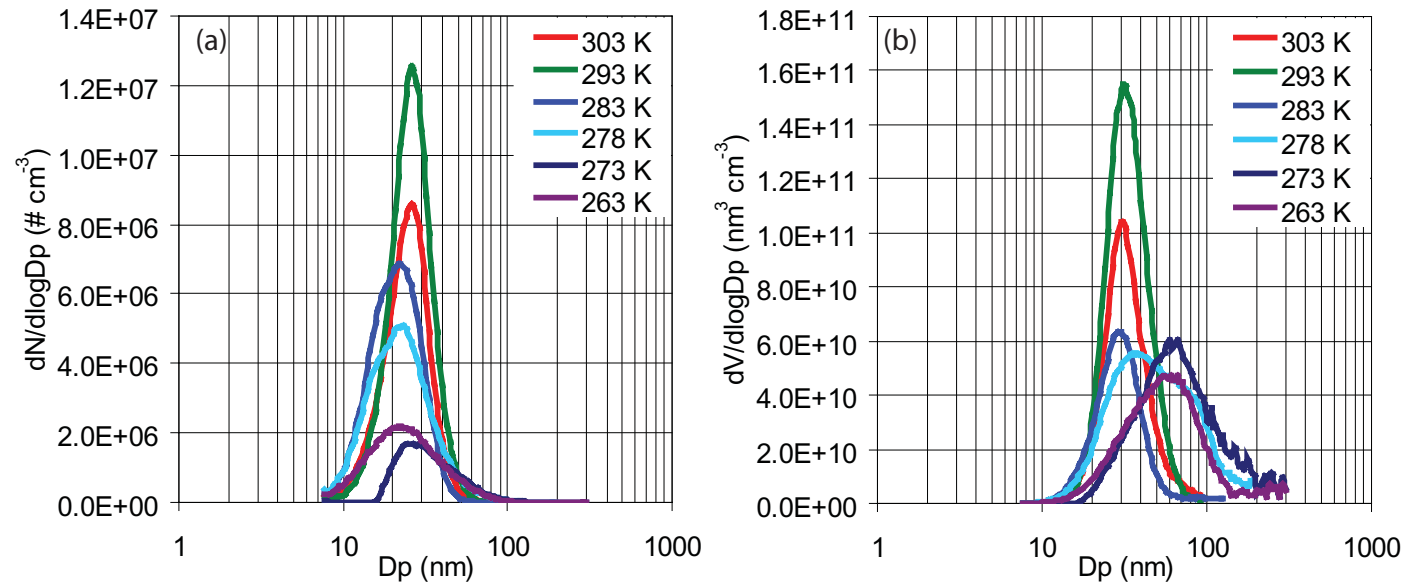

\section{Temperature dependence of SOA yield \\ C. Stenby et al.}

Title Page

Abstract

Introduction

Conclusions

References

Tables

Figures

14

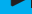

Back

Full Screen / Esc

Printer-friendly Version

Interactive Discussion 


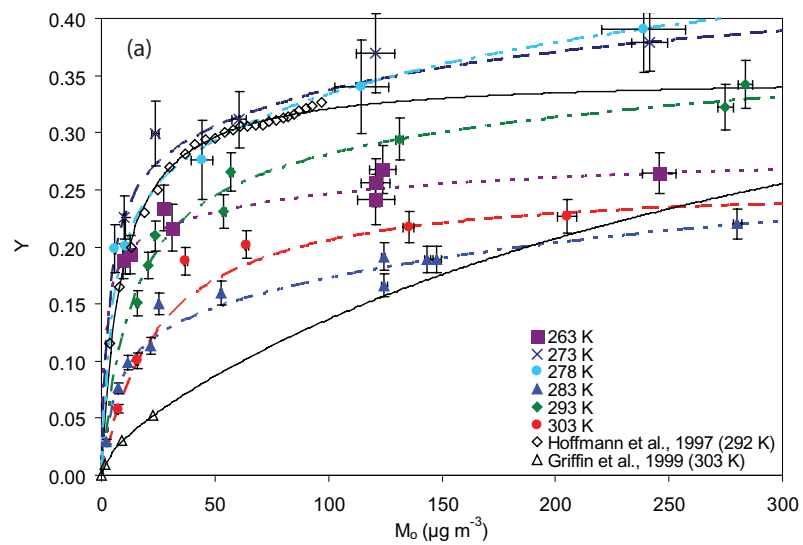

\section{ACPD}

6, 10275-10297, 2006

\section{Temperature dependence of SOA yield}

C. Stenby et al.

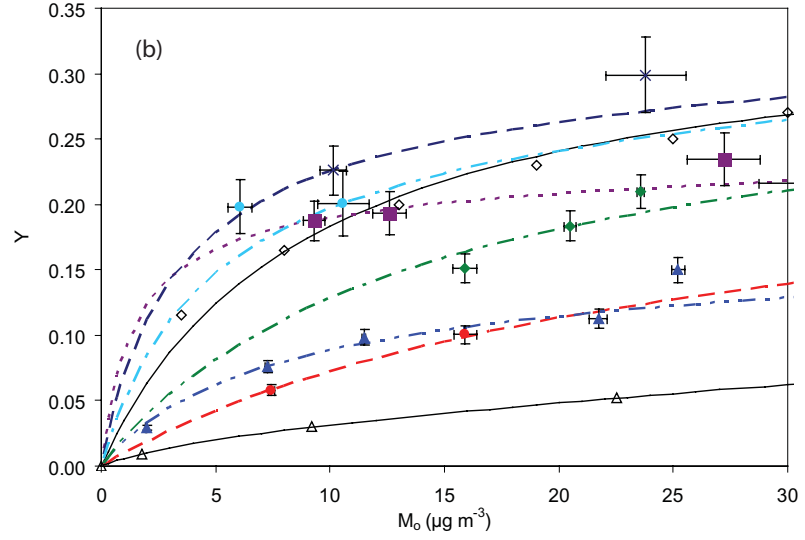

Title Page

Abstract

Introduction

Conclusions

References

Tables

Figures

14

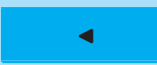

Back

Close

Full Screen / Esc

Fig. 3. Secondary organic aerosol yield $(Y)$ plotted against particle mass concentration $\left(M_{o}\right)$ from experiments performed at different temperatures (263-303 K): (a) all data from this study (Table 1), and earlier studies; (b) blow-up of low $M_{o}$ range from panel (a). Symbols and error bars represent the arithmetic mean and standard deviations of 4-24 replicate measurements performed in each experiment. Lines are fitted with the two product model.

Printer-friendly Version

Interactive Discussion 


\section{ACPD}

6, 10275-10297, 2006
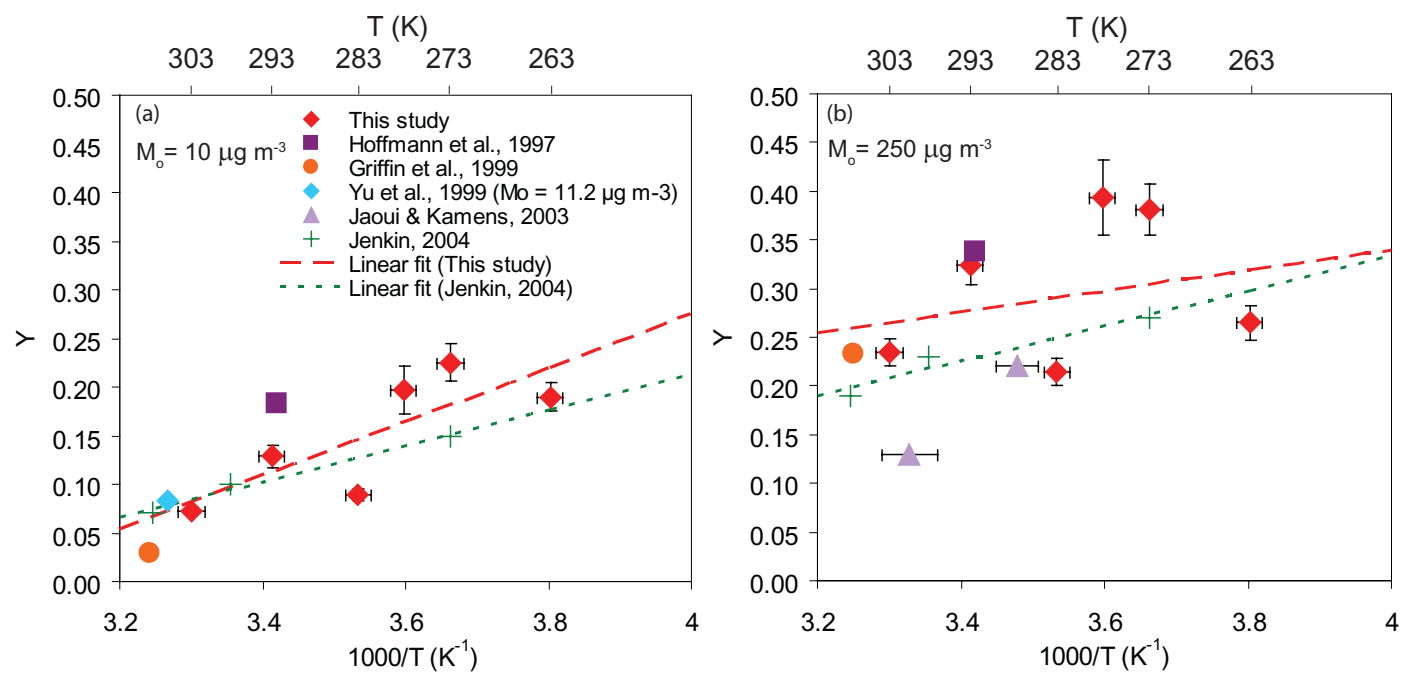

\section{Temperature dependence of SOA yield \\ C. Stenby et al.}

Fig. 4. Aerosol yield $(Y)$ plotted against inverse temperature (1000/T): (a) $M_{o}=10 \mu \mathrm{g} \mathrm{m}^{-3}$; (b): $M_{o}=250 \mu \mathrm{g} \mathrm{m}^{-3}$. The symbols represent measurement or two-product model results of different studies. The error bars of the yield represent the standard deviations of 4-24 replicate measurements from our experiments with $M_{o}$ close to $10 \mu \mathrm{g} \mathrm{m}^{-3}$ or $250 \mu \mathrm{g} \mathrm{m}^{-3}$, respectively. The error bars of the temperature represent the confidence interval of the thermo sensors applied in our study and the range of temperatures reported in other studies. Lines are linear fits.

Title Page

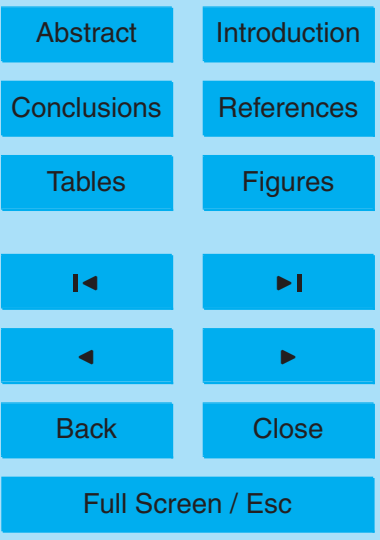

Printer-friendly Version

Interactive Discussion 